\title{
Hekime Tanı Koymada Yardımcı, Yapay Zekâ Destekli Hastalık Tespit Uzmanı*
}

\author{
Ethem Karal ${ }^{1 \dagger}$, Metin Turan ${ }^{2}$ \\ ${ }^{1 *}$ İstanbul Ticaret Üniversitesi, Mühendislik Fakültesi, Bilgisayar Mühendisliği Bölümü, İstanbul, Türkiye, (ORCID: 0000-0002-3404-4322), ethemkaral@gmail.com \\ 2 İstanbul Ticaret Üniversitesi, Mühendislik Fakültesi, Bilgisayar Mühendisliği Bölümü, İstanbul, Türkiye (ORCID: 0000-0002-1941-6693), mturan@ticaret.edu.tr
}

(3rd International Congress on Human-Computer Interaction, Optimization and Robotic Applications June 11-13, 2021)

(DOI: 10.31590 /ejosat.945518)

ATIF/REFERENCE: Karal, E. \& Turan, M. (2021). Hekime Tanı Koymada Yardımcı, Yapay Zekâ Destekli Hastalık Tespit Uzman1. Avrupa Bilim ve Teknoloji Dergisi, (26), 100-116.

\section{$\ddot{O} \mathbf{z}$}

Bu çalışma, makine öğrenmesi, veri madenciliği ve yapay zekâ teknolojileri kullanılarak, hastaya tanı konulmasını kolaylaştırmayı hedeflemektedir. Doğal dil işleme süreçleri ile hasta anamnezleri değerlendirilerek, tanı koymada yardımcı bir sistem oluşturulmuştur. Oluşturulan sistem ile hastadan anamnez alınırken doğal dil işleme kullanılarak; her bir hastalık belirtisi içeren konu başlı̆̆ önce anlamlandırılır, sonra kategorize edilerek eğitim yapılır.

Karar Ağaç (Decision Tree), Torbalama (Bagging), Arttırma (Boosting) kullanılarak öğrenme işlemleri gerçekleştirilmiştir. Öykü alma sırasında bilinen hastalıkların belirtileri değerlendirilerek doktorların yükünü hafifletmek amaçlanırken, pandemi gibi dönemlerde ya da yeni ortaya çıkan ve belirtileri/tedavi yöntemleri/hasta sayısı konularında az veriye sahip olunan dönemlerde, sağlık çalışanlarına ve sağlı sistemine yardımcı bir sistem geliştirilmesi hedeflenmiştir.

Oluşturulmuş bu sistem; doktorların, hastaların rahatsızlıklarını daha yüksek doğruluk ve verimlilikle teşhis etmesine yardımcı olmuştur. Alınan bilgiler doğrultusunda Karar Ağaçları yöntemi ile bulunan doğruluk oranı \%73, Random Forest algoritması ve Entropi ölçüsü kullanılarak ulaşılan doğruluk oranı \%76, aynı algoritmanın Gini ölçüsü ile ulaşılan doğruluk oranı \%82'dir. Adaboost algoritması kullanıldığında, öğrenme sabiti 1.0 olduğu durumda \%64 sonucu elde edilirken, öğrenme sabiti 0.5 alındığında doğruluk oranı \%67 olarak bulunmuştur.

Hastanın anamnez verilerini değerlendiren sistem, hekime olası sonuçların listesini sunarak hekimin işini kolaylaştırmıştır. Yapay zekânın sonuçlarını değerlendirerek sonuçlara katılmak ya da katılmamak ise tamamen doktorun tercihine bırakılmıştır.

Anahtar Kelimeler: Hastalık Tespit Sistemi, Doğal Dil İşleme, Makine Öğrenmesi, Yapay Zekâ.

\section{Assistant in Diagnosis for Doctor, Artificial Intelligence Supported Disease Detection Specialist}

\begin{abstract}
This article aims to facilitate the diagnosis of the patient by using machine learning, data mining and artificial intelligence technologies. With natural language processing processes, patient anamnesis was evaluated and an auxiliary system was created for diagnosis. By using natural language processing while taking anamnesis from the patient with the system created; The topic containing each disease symptom is first made meaningful, then categorized and training is carried out.

Learning operations were carried out using Decision Tree, Bagging and Boosting. While it is aimed to alleviate the burden of doctors by evaluating the symptoms of known diseases during history taking, it is aimed to develop a system that helps healthcare professionals

\footnotetext{
* Bu makale İstanbul Ticaret Üniversitesi Fen Bilimleri Enstitüsü Bilgisayar Mühendisliği Yüksek Lisans Programı Dr. Öğr. Üyesi Metin Turan danışmanlığında Ethem Karal'ın yürüttüğü "Hekime Tanı Koymada Yardımcı, Yapay Zeka Destekli Hastalık Tespit Uzmanı" başlıklı yüksek lisans tezi çalışmalarından yararlanılarak hazırlanmıştır.
}

† Sorumlu Yazar: ethemkaral@gmail.com
\end{abstract}


and the health system during periods such as pandemics or when there is little data on symptoms / treatment methods / number of patients.

This system created; helped doctors diagnose patients' ailments with higher accuracy and efficiency. In line with the information received, the accuracy rate found with the Decision Trees method is $73 \%$, the accuracy rate achieved by using the Random Forest algorithm and the Entropy measure is $76 \%$, and the accuracy rate achieved with the Gini measure of the same algorithm is $82 \%$. When the Adaboost algorithm was used, when the learning constant was 1.0 , the result was $64 \%$, and when the learning constant was 0.5 , the accuracy rate was found to be $67 \%$.

The system, which evaluates the patient's anamnesis data, has facilitated the physician's work by presenting a list of possible results to the physician. Evaluating the results of artificial intelligence, whether or not to agree with the results is entirely up to the doctor's choice. Keywords: Artificial Intelligence, Disease Detection System, Natural Language Processing, Machine Learning.

\section{Giriş}

Günümüzde makine öğrenmesi ve yapay zeka; doktorları, hastaları, hastaneleri ve sağlı ile ilgili tüm alanları etkilemeye başlamıştır. Bilgisayarlı tomografiler, diyabetik retinopati analizi, EKG ile kalp krizi riski belirlenmesi gibi alanlarda hali hazırda yapay zekâ ve makine öğrenmesi yöntemleri kullanılmaktadır. Bu alanlarda bol miktarda veri olduğu için algoritmalar teşhis koyma konusunda en az uzman doktorlar kadar başarılı olabilmektedirler.

Hasta ve doktor ilişkisinin ön planda olduğu ve hasta mahremiyetinin sağlanması gereken anamnez alma (hasta öyküsü) gibi alanlarda ise yapay zekâ çalışmaları devam etmektedir. Anamnez alma, hastalığın teşhisi için en önemli adımlardan biridir. Anamnez sayesinde gereksiz tetkik ve araştırmalar engellenir ve bu sayede zaman ve para kaybı önlenmiş olur. Doktorlar veri girişi ve masa başı işlere, hastalara ayırdıklarından daha fazla zaman ayırmaktadırlar. Dünya nüfusunun giderek yaşlandığı ve doktor ihtiyacının sürekli arttığ düşünülürse, kazanılan her saniye, çok sayıda insanın sağlığına kavuşmasına yardımcı olacaktır.

Anamnez alma sürecinde; veri girişi ve sonuçların analizinde, yapay zeka yöntemleri kullanılması durumunda potansiyel sorunlar önceden tespit edilerek hekim bilgilendirilebilir. Bu sayede tanı koymada hekime yardımcı olunarak fayda sağlanırken, hekimlerin hastalar ile daha verimli zaman geçirmeleri sağlanabilir. Aynı zamanda yapay zeka yöntemleri, hekimlere zaman kazandırmanın yanında; atlanan ve boşa giden verileri de derleyerek analiz edebilirler. Yapılan bir araştırmaya göre; bir hastane her sene 50 petabyte veri üretmektedir. Ancak bu verilerin \%97'si hiç kullanılmamaktadır (Kellner, 2017). Yapay zeka; bu verileri de analiz ederek teşhis ve tedavi için yeni yöntemler ortaya çıkarma potansiyeline sahiptir.

Bu çalışmada; hekime yardımcı olarak geliştirilen yapay zeka platformu, hekimin hastadan alacağı bilgileri baz alarak çalışmaktadır. Önce aldığı tüm verileri ayıklayıp anlamlandırarak kategorilendirecektir. Eğitim yapıldıktan sonra hastalığın teşhisine yönelik sonuçlar hekime sunulacaktır. $\mathrm{Bu}$ süreç sayesinde hem doktorun iş yükü azalarak hasta ile daha verimli zaman geçirebilecek, hem de pandemi gibi bulaşıcı hastalık dönemlerinde hasta ve hekimin izolasyonu sağlanacaktır.

Üzerinde çalışılan hekime tanı koymada yardımcı olması hedeflenen bu sistem, otomasyon sistemlerinin tersine, varyasyon ve esneklik sağlamaktadır. Teşhis koyma, yasal sorumluluğu hekime ait olan bir süreçtir. Bu sistem ile doktora sadece; alınan verilerin değerlendirilmesi ile elde edilen sonuçlar

sunulacaktır. Sistemin koyduğu teşhis hekime bir öneri ve yönlendirme niteliği taşımaktadır. Bu noktada doktor; yapay zekanın teşhisini onaylayabilir ve kendi koyduğu teşhisin doğruluğunu pekiştirebilir. Bir diğer seçenek olarak; yapay zekanın koyduğu teşhisi yetersiz ya da geçersiz bulabilir. $\mathrm{Bu}$ durumda kendisi ek tetkikleri yaparak tanı hakkındaki son kararı kendisi verecektir.

\section{Materyal ve Metot}

\subsection{Veri Madenciliği ve Yapay Zekâ Yöntemleri Kullanarak Öykü (Anamnez) Alma}

\subsection{1. Öykü (Anamnez) Alma}

Hekim ya da sağlık çalışanlarının hasta adayına teşhis koymak veya mevcut hastalığının durumunu tesbit etmek için sorular sorarak bilgi almasına anamnez almak denir. Anamnez soruları belirli bir sıra ve düzen ile hastaya yönlendirilir. İyi bir anamnez tanısı, fizik muayeneden daha fazla ipucu barındırır. Anamnez alındıktan sonra, fizik muayene ve laboratuvar (kan, görüntüleme vb) sonuçları ile teşhis için gerekli bilgiler elde edilir (Tarhan, 2015). Hekimin hastayı görsel olarak muayene etmesinden sonra sıra sesli iletişim kurmaya geçmektedir. Hekimler, anamnez sürecinin ikinci kısmında hastaya belirli kategoriler altında sorular yöneltir. Bu kategoriler kendi içinde ikiye ayrılır: Genel Durum Öyküleri ve Belirli Sistemlere Yönelik Öyküler. Sorulan sorular hastalığın tanısını koymada büyük önem taşır.

\subsection{2. Öykü (Anamnez) Almanın Önemi}

Anamnez, hastalara tanı koyulmasında çok önemli rol oynar, özel önlem gereken sistemik hastalıklar öğrenilir, kullandığg ilaçlar, bazı sistemik hastalıklar gibi birçok bilgiye ulaşılır. Doktorlar hastayı görmeden önce, hastanın daha önce oluşturulmuş tıbbi bilgiler içeren kartı hastanın önceden geçirdiği rahatsızlıklar ve hastalıklarının seyri hakkında bilgi verir.

Hastanın adı, cinsiyeti, yaşı, ana-baba adı, doğum yeri-ve ailenin geldiği yer, öykünün alınış tarihi, saati gibi içerikler olmalıdır. Cinsiyet özel işaretlerle veya yazılı ifadelerle belirtilir. Hastanın doğum yeri ya da yaşadığı yer önemli ipuçları verebilir. Pediatrik öykü (anamnez) şu ana bölümlerden oluşur : - Yakınma - Öykü ve sistem soruları - Özgeçmiş - Soygeçmiş (Fakültesi, 2016).

Teşhis konulurken ilk aşama olarak hastalık için gerekli bilgiler toplanır. Hastanın şikayetini anlatırken kullandığ terimler, doktorun muayenelerden sonraki tesbitleri ve laboratuvar test sonuçları bir araya getirilir. İkinci aşamada, elde edilen tüm bilgiler yorumlanarak bu bilgilerin klinik önemi değerlendirilir. Anamnez alınırken; hasta anamnezi, aile anamnezi, sosyal anamnez birlikte alınır ve değerlendirilir. Böylece olası bir sistemik hastalık belirtisi farkedilmeye çalışılır. Hasta anamnezi; biyografik bilgiler, esas şikayet ve onun öyküsü, sosyal hikaye, aile hikayesi, davranış ve duygusal hikaye, tıbbi hikaye ve sistemlerin incelenmesi (geçmişteki ve şu andaki) ve dental hikayeyi içerir (Nalçac1, 2015). Hasta özgeçmişine ait anamnez bilgileri Tablo 1'de yer almaktadır. Esas şikayetin tesbit 
edilmesi için sorulacak anamnez bilgileri Tablo 2'de verilmiştir. Hasta aile öyküsü bilgileri Tablo 3'te, hastanın kişisel ve sosyal öyküsü Tablo 4'te görülmektedir.

Tablo 1. Hasta Özgeçmişi (Nalçacı, 2015)

\begin{tabular}{l} 
Hastanın Özgeçmişi \\
\hline Yaş? \\
\hline Boy? \\
\hline Kilo? (kg) \\
\hline Yaşamını sürdürdüğü ortam? \\
\hline Kaza - travma \\
\hline Alerji, pika, parazit \\
\hline Aşılama \\
\hline Cinsiyet? (Erkek) \\
\hline Cinsiyet? (Kadın) \\
\hline Gebelik var? yok? \\
\hline Gebelik öyküsü (Alkol, sigara vb.) \\
\hline Gebelik süresi, doğum şekli \\
\hline Gebelikte geçirilen hastalıklar \\
\hline Gebelik olunan aşılar \\
\hline Doğum sonrası sorunlar \\
\hline Psikomotor gelişim \\
\hline Beslenme(anne sütü, ek gıda vb.) \\
\hline
\end{tabular}

Tablo 2. Hasta Ă̆rı Öyküsü

\begin{tabular}{l} 
Ăgrı olduğu durumda: Ăgrı öyküsü \\
\hline Yeri \\
\hline Başlangıcı \\
\hline Özellik \\
\hline Yayılım \\
\hline İlişkileri \\
\hline Zamanlaması \\
\hline \multicolumn{2}{|}{ Tablo 3. Hasta Aile Öyküsü } \\
\hline
\end{tabular}

Aile öyküsü

\begin{tabular}{l}
\hline Akraba Evliliği \\
Anne - baba sağlığı / ölüm nedeni \\
Kalp, Tansiyon, astım vb. genetik olarak gelen hastalıklar \\
\hline
\end{tabular}

Tablo 4. Hasta Kişisel ve Sosyal Öykü

Kişisel ve Sosyal öykü

\begin{tabular}{l}
\hline Alkol, sigara, uyuşturucu kullanımı \\
\hline HIV var mı? AIDS var mı? \\
\hline Riskli bir mesleğe sahip mi? \\
\hline Evcil hayvan var mı? \\
\hline Vücut kitle endeksi nedir? \\
\hline Yaşamını sürdürdüğ̈ ortam nasıl? \\
\hline
\end{tabular}

Anamnez alınırken sorular rastgele değil, belirli bir düzen ve sıra ile sorulur. Hasta ve doktor ilişkisinin güven içermesi, sağlıklı bir iletişim kurulması ve doğru sonuçlara/tedavi yöntemlerine ulaşılması doğru ve yeterli bir anamnez alınmasına bağlıdır.
Anamnez sırasında Genel Durum Öyküleri kategorisi altında sorulan sorular ve kendi içindeki kategoriler tablolarla belirtilmiştir (Alçelik, 2016). 
Tablo 1, Tablo 2, Tablo 3 ve Tablo 4'te bulunan anamnez sorularının sorulmasindan sonra, hastaya Tablo 5'te bulunan Genel Durum Öyküleri anamnez soruları yöneltilir.

Tablo 5. Hasta Genel Öyküsü

\begin{tabular}{l}
\hline Genel öykü \\
\hline Yorgunluk / Kırgınlık \\
\hline Ateş \\
\hline Titreme \\
\hline İştah artışı \\
\hline Kilo Kaybı \\
\hline Ciltte kızarma / morarma \\
\hline Uyku bozukluğu \\
\hline Hayattan zevk alamama \\
\hline Sinirlilik \\
\hline Baş dönmesi \\
\hline Bacaklarda ödem \\
\hline Kas veya eklem ağrısı \\
\hline Gözlerde ciltte sararma \\
\hline Gözlerde yanma ve sulanma hissi \\
\hline El ve ayak parmaklarında renk değişikliği \\
\hline
\end{tabular}

Kardiyovasküler değerlendirmeye yönelik elde edilecek veriler; göğüs ağrısı, nefes darlığı, çarpıntı, ritim bozukluğu, solgunluk ve ödem, özgeçmiş, soygeçmiş ve kişisel alışkanlıklardır. Hastada varolan tüm belirtiler belli bir düzen içinde sorgulanmalı, belirtinin ne zaman başladığı, nasıl yayıldığı ve diğer belirtiler, tedavisi için neler yapıldı̆̆ gibi bilgiler hastadan ya da yakınından alınmalıdır (Sevinç, 2006). Kardiyovasküler sistem öyküsü basamakları Tabla 6'da verilmiştir.

Tablo 6. Hasta Kardiyovasküler Sistem Öyküsü

\begin{tabular}{l} 
Kardiyovasküler Sistem Öyküsü \\
\hline Göğüs ağrısı \\
\hline Boğazda ağrı / yanma \\
\hline Kulaklarda dolgunluk \\
\hline Burunda tıkanıklık / akıntı \\
\hline Tat veya koku kaybı \\
\hline Hapşırma \\
\hline Ağı kuruluğu \\
\hline Baş/Göğüs ağrısı \\
\hline Kalp ritim bozukluğu \\
\hline Çarpıntı \\
\hline Aile Öyküsü \\
\hline Sosyal Öykü \\
\hline Alerjiler \\
\hline
\end{tabular}

Gastrointestinal sistem (GİS) hastalıkları oldukça geniş bir hastalık grubunundan oluşmaktadır. Hekimlerin vakalar karşısında doğru teşhis koyabilmeleri için; gastroenterolojinin temel bilgilerini ve hastalık semptomlarını yakından tanımaları ve bu alanda yeterli tecrübeye sahip olmaları gerekir. Semptom; hasta tarafından hissedilen (sübjektif ) baş ağrısı, baş dönmesi, bulantı, halsizlik gibi belirtilerdir. Hekimin muayene sırasında saptadığı ödem, sarılık ve siyanoz gibi objektif bulgulara ise sign denmektedir (Uygun, 2009). Hasta Gastrointestinal Öyküsüne ait bölümler Tablo 7'de verilmiştir. 


\begin{tabular}{l} 
Gastrointestinal öykü \\
\hline İştah kaybı \\
\hline Normal/Kanlı kusma \\
\hline Karın ağrısı \\
\hline İshal \\
\hline Hazım (Sindirim) zorluğu \\
\hline Mide bulantısı \\
\hline
\end{tabular}

Göğüs Hastalıkları alanında anamnez alınırken; diğer tüm sistemlerde olduğu gibi hastanın kimlik bilgileri (ad, soyad, doğum tarihi, doğum yeri, cinsiyet, medeni durum, meslek) ile sorulara başlanır. Sonrasında hastanın başlıca yakınması/yakınmaları, bu yakınmaların ne zaman başladığı, yakınmaların süreç boyunca nasıl ilerlediği, yakınmaları nelerin tetiklediği sorulur. Hastanın daha önce geçirdiği rahatsızlıklar sorularak anamnez sürecine devam edilir.

Solunum sisteminin başlıca semptomları;

Öksürük

\section{Balgam çıkarma \\ Nefes darlığ 1 \\ Göğüs ağrısı}

Her semptom tek tek sorgulanmalıdır. Gögüs ağrısından yakınan hastaya çeşitli sorular sorularak özellikle kardiyak-plöretik ağrı ayırt edilmelidir. Ağrının ne zaman başladığı, yeri, yayılımı, niteliği, nelerle tetiklenip hafiflediği ve eşlik eden semptomlar sorulmalidir (Oya Kayacan, 2018). Hasta Solunum Yolu Öyküsüne Tablo 8'de yer verilmiştir.

Tablo 8. Hasta Solunum Öyküsü

\begin{tabular}{|l|}
\hline Solunum Yolu Öyküsü \\
\hline Öksürük \\
\hline Balgam \\
\hline Ağır solunum yetmezliği \\
\hline Nefes darlığı \\
\hline Hırıltı solunum \\
\hline Gögüs ağrısı \\
\hline Alerjiler \\
\hline Hızlı soluk alıp verme \\
\hline Genel Semptomlar \\
\hline Sosyal Öykü \\
\hline
\end{tabular}

Sorulan sorulara karşılık verilen cevaplar içerisinden toplam 130 kişiden veri toplanarak işlemler yapılmıştır. Her bir hastalık çeşidine göre alınan veriler anlamlandırılmaya çalışılır. Her sorunun cevabı tek cevap yerine çoklu cevaplar olması durumunda alınan veri çoklu bölümler halinde ön işleme yapmak üzere algoritmaya gönderilir. Yukarıda belirtilen hasta öykü bilgilerinin anket yardımı ile alınan sonuçları aşağıda yer almaktadir.

Bu Çalışma için oluşturulmuş olan "Hekime Tanı Koymada Yardımcı, Yapay Zeka Destekli Hastalık Tespit Uzmanı" isimli çalışmamız için önerdiğimiz anket soruları İstanbul Ticaret Üniversitesi Rektörlüğü Etik Kurul onay1 "9.4.2021” tarihli ve “E-65836846-044-207508” sayılı ile onaylanmıştır.

Tuzla Marmara Üniversitesi Pendik E. A. H. Eğitim Aile Sağlığı Merkezinde görevli olan doktorlar ile çalışma süresi boyunca görüşerek bilgi alındı. Ancak araştırma hastanesine bağlı olduğu için çalışan doktorların belirli zaman aralıklarında sürekli değişmesi söz konusuydu. Bu durum söz konusu olduğundan görüşmeler sırasında görüşülen doktorlarda buna bağlı olarak değişim gösterdi.

\subsection{3. Öykü (Anamnez) Alma Anket Sonuçlart}

Hastanın özgeçmişinde genel bilgi alınırken diğer bölümlerdeki sorular ile hastalık ile ilişkili vücut kısımlarına ait özel sorular yöneltilmiştir. Özgeçmişte, kısa şekilde geçmiş tıbbi ve cerrahi bilgi alınır. Bu sayede kişinin şuanki hastalık ile ilişkili herhangi bir hastalık geçirip geçirmediği kontrol edilir. Cinsiyete bağlı olarak farklı sorular yönlendirilir. Böylece; kadınlar için doğum yapmış olma, gebelik sırasında geçirilen hastalıklar ve olunan aşılar gibi bilgilerin yanı sıra erkekler için anamnez sırasında sorulan sigara, alkol ve uyuşturucu kullanımı, beden kitle endeksi gibi bilgiler de alınır. Aile öyküsü ile genetik hastalıkların tespiti yapılması amaçlanmıştır. Belirlenen hastalıklar ile ilgili vücut sistemleri için tek tek bölümler oluşturulmuş, bu bölümlerde belirtilere yönelik sorular sorulmuştur. Sonrasında bu sistemlerin birbirleri ile ilişkileri incelenerek anamnez alma süreci tamamlanır. Anamnezde yer alan hastalıklardan, öyküsü alınan kişilerin hastalığının tanısı konulması hedeflenmiştir.

Anamnez (Öykü) aldığımız anket sonuçlarından bazı bilgiler aşağıda yer almaktadır. Anamnez sırasında 130 denek kişi ile çalışma yapılmış olup toplamda 7 hastalık çeşidine göre bilgilerin doldurulması istenmiştir. 


\section{Şekil 1. Hastalık İsimleri}

Aşağıdaki hastalıklardan geçirmiş olduğunuzu işaretleyiniz? (Birden fazlasını geçirdiyseniz en son geçirmiş olduğunuz hastalığı işaretleyiniz.)

130 yanıt

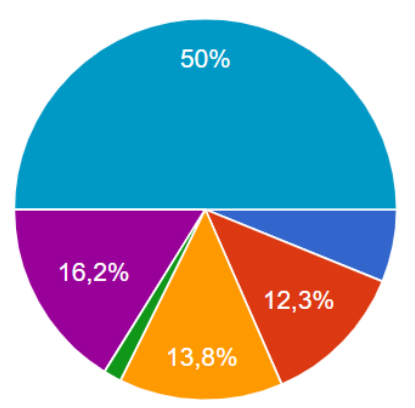

Zatürre

Akut Bronşit

Astım

Koah

Covid-19

Mevsimsel Grip

Hepatit A-B-C

Yap1lan anket sonucunda; 65 mevsimsel grip, 21 Covid-19, 18 Astım, 16 Akut Bronşit, 8 Zatürre, 2 Koah ve 0 Hepatit A-B-C kişi belirtilen hastalıkları işaretlemiştir. Çalışmada belirtilen

hastalıklar ile verilen cevaplara göre kişinin hangi tip hastalığa yakın olabileceği tespiti yapılmaktadır.

\section{Şekil 2. Ăgrının yerleşim yeri ve şiddeti}
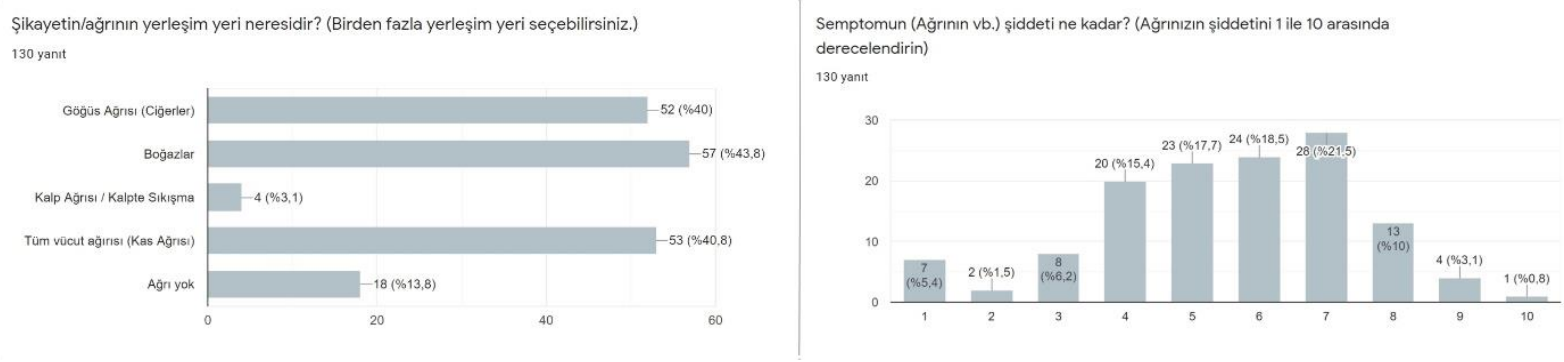

Şekil 3. A ̈̆rıyı artıran ve azaltan nedenler

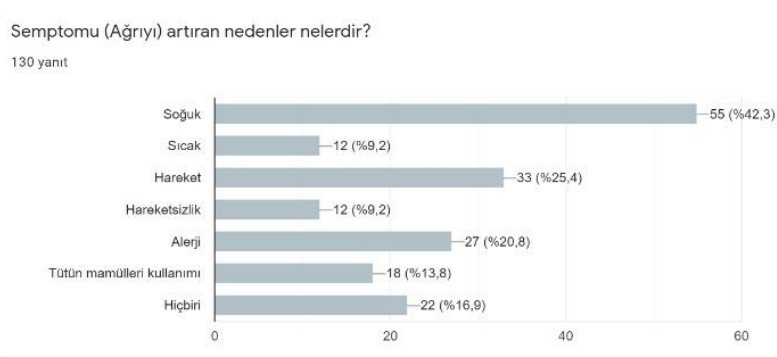

Şekil 2, Şekil 3'te alınan cevaplar ile hastalığı etkileyen sebepler ve eşlik eden herhangi bir belirti olup olmadığ araştırılmıştır. Ayrıca Şekil 4, Şekil 5 ve Şekil 6'da verildiği üzeregeçmişte hastalık ile ilgili geçirilen ameliyat olup olmadığ

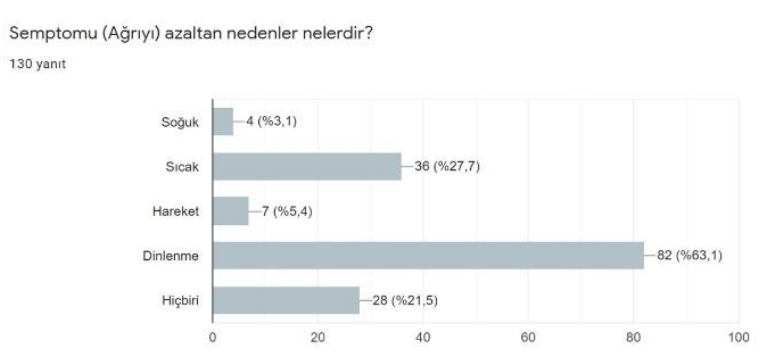

ve kişinin hastane geçmişi hakkında bilgi edinilmeye çalışılmıştır. 


\section{Avrupa Bilim ve Teknoloji Dergisi}

Şekil 4. Geçmişte geçirilen hastalıklar ve alınan tedavi yöntemleri

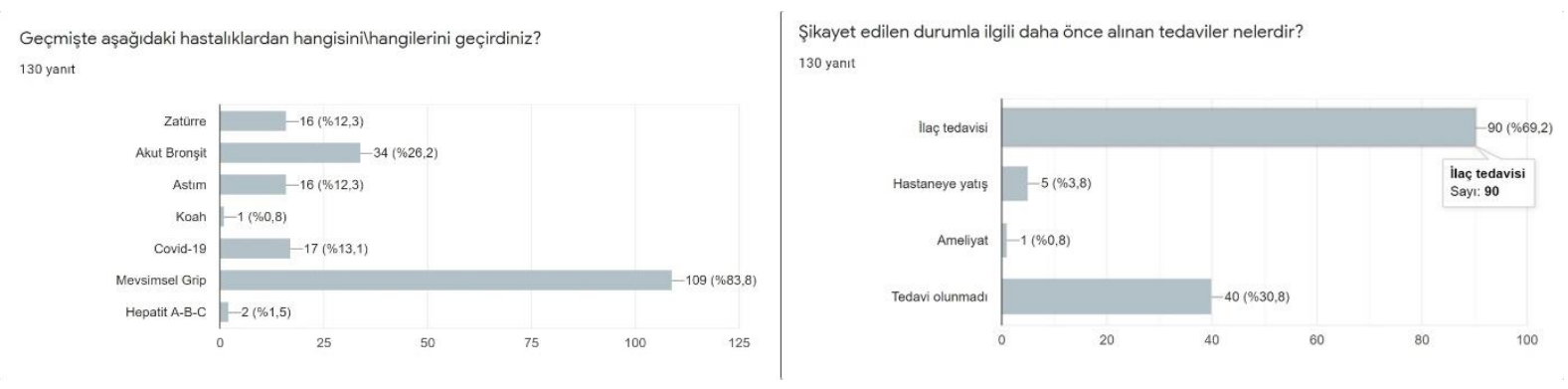

Şekil 5. Hastaneye yatış ve ameliyat geçirilme durumu
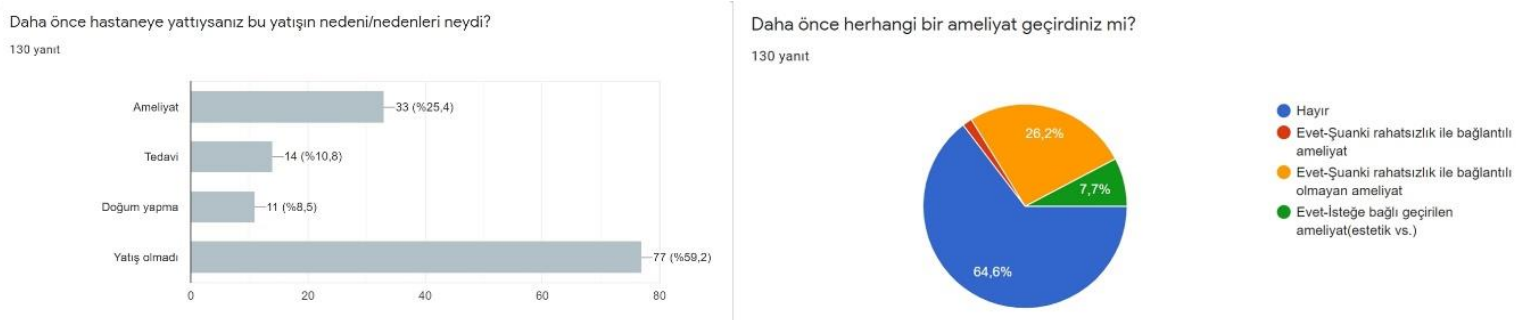

Meslek hastalığı veya bağımlılık yapıcı maddeler ile herhangi bir bağ olup olmadığı değerlendirmek amaçlanmıştır.

Aşağıda belirtilen tabloda meslek gruplarına göre bilgiler yer almaktadır.

Şekil 6. Meslek grupları ve kullanılan bağımlılık yapan madde çeşitleri
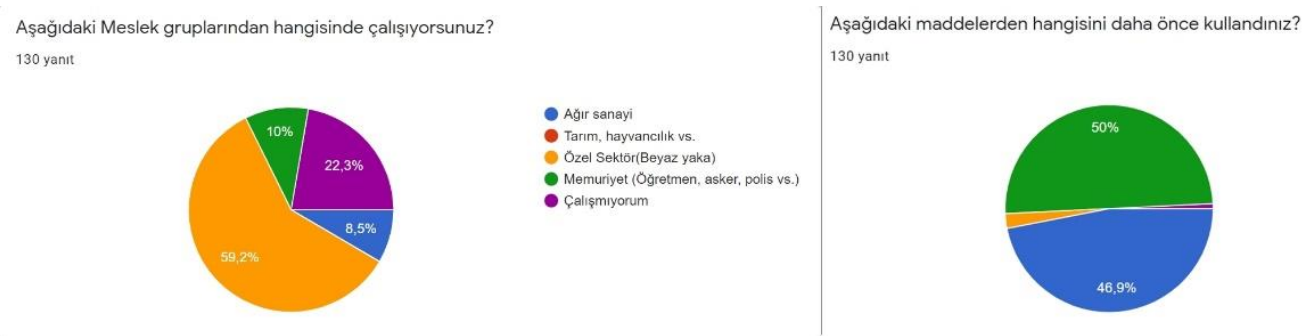

- Sigara

- Uyusturu

- Hepsbiri

- Sigara (Gonlok Kag Paket

Şekil 7. Günlük tüketilen sigara paketi sayısı

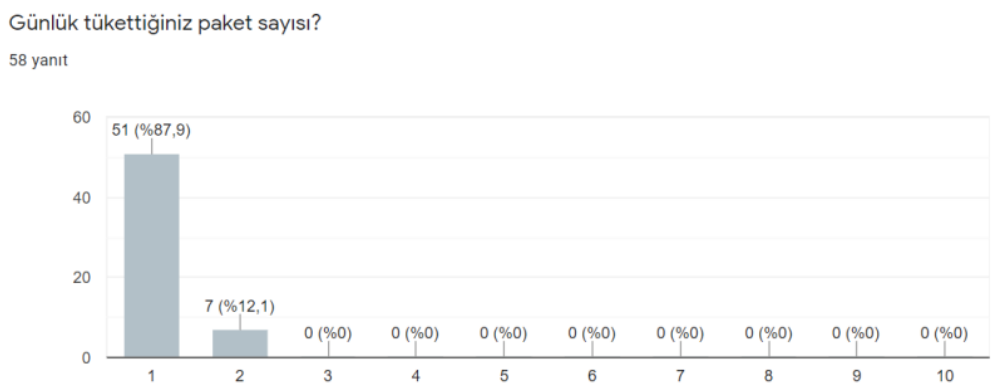


Şekil 8. Gastrointestinal, KBB ve Kardiyovasküler Sistemler
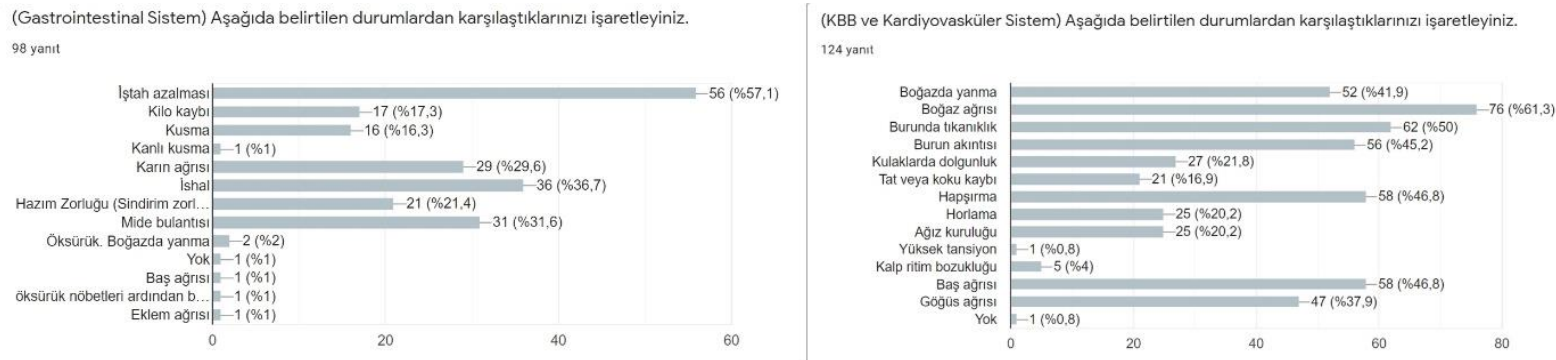

Sekil 9. Solunum ve Genel Sistemler

(Solunum Sistemi) Aşağıda belirtilen durumlardan karşılaştıklarınızı işaretleyiniz. 125 yant

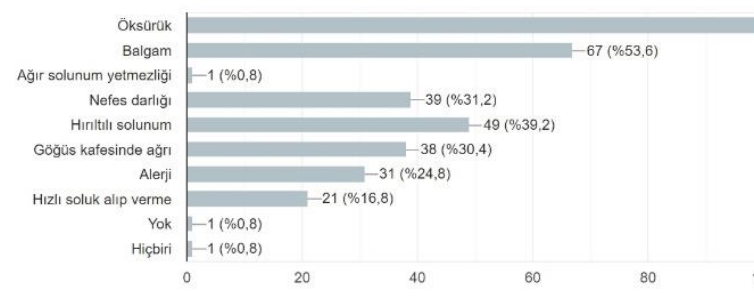

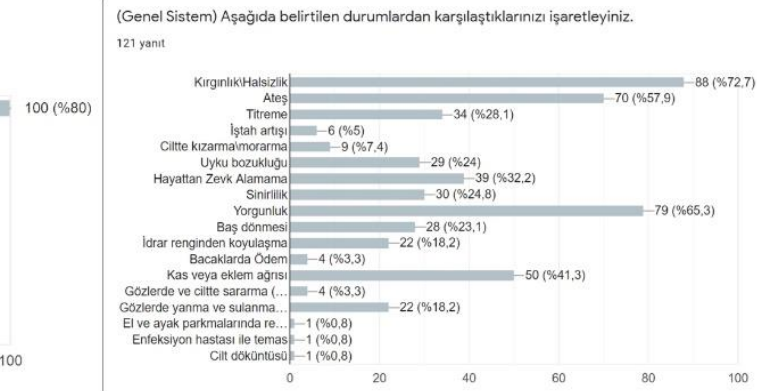

\subsubsection{Vücut Kitle İndeksinin Bu Araştırma İçin Önemi}

Obezite kilo ve boy değerleri alınarak hesaplanır. Hesaplama için kilonun boy değerinin karesine bölünmesiyle $\left(\mathrm{kg} / \mathrm{m}^{2}\right)$ hesaplanır. Vücut kitle indeksi sonuçlarına göre 30'un üzeri obez, 40'un üzeri morbid obez, 50'nin üzeri süper obez olarak adlandırılır (Acıbadem, 2021). Obezlik ya da aşırı zayıflık gibi durumların hangi hastalıklarda ne derece etkisi olduğu değerlendirilmiştir.

Vücut kitle indeksi(VKİ) hesaplaması, obeziteyi hesaplamak için tüm dünyada standart olarak kullanılmaktadır. VKİ hesaplanırken; kişinin kilogram cinsinden ağırlığının ölçüsü, kişinin metre cinsinden boy uzunluğunun karesine bölünür $\left(\mathrm{kg} / \mathrm{m}^{2}\right)$.

$18,5 \mathrm{~kg} / \mathrm{m}$.'den düşük bireyler: Zayıf birey

$18.5-24,9 \mathrm{~kg} / \mathrm{m}$. Arasındaki bireyler: Normal kilolu birey

$25-29,9 \mathrm{~kg} / \mathrm{m}$. Arasındaki bireyler: Fazla kilolu birey

$30-39,9 \mathrm{~kg} / \mathrm{m}$. Arasında bireyler: Obez birey

40 kg/m.'nin Üzerinde bireyler: İleri derecede obez birey(morbid obez), olarak tanımlandirılir.

\subsection{5. Öykü (Anamnez) Alma ile Alınan Verilerin Anlamlandırlmasinda Metin Temizleme}

$\mathrm{Bu}$ çalışmada anamnez ile alınan verilerden eğitim kümeleri oluşturulmuştur. Bu eğitim kümeleri üzerinde ön işleme (kelime ayrıştırma, etkisiz sözcükleri (stop word) eleme, eş anlamlıları bulma, tekrar eden karakterlerin elenmesi, yanlış yazılmış kelime düzeltme, kök bulma) çalışması yapılmıştır. Aşağıda tüm adımlar tek tek verilmiştir.

\subsubsection{1. Ön Isşleme}

Dil işleme algoritmalarını kullanmadan önce, üzerinde çeşitli ön işleme işlemleri gerçekleştirilir. Bunun nedeni, metinleri arındırmaktır. Ön işleme aşamasında her bir satırdaki hastalığın anamnez sonuçlarına göre metin tek bir bütün olarak değil gruplara ayrılarak aşama aşama ön işleme adımlarına geçilir. Ayrılan gruplarda eğer tekli bir seçim varsa; yalnızca tek bir cevap var/yok olarak değerlendirilerek oluşturulan dosyaya (.csv, .xml) yeni bir veri olarak eklenir. Grup içerisinde birden fazla çoklu seçim olduğu durumda öncelikle çoklu seçim tek bir seçim olacak şekilde indirgenmesi yapılarak her cevap ayrı ayrı oluşturulan dosyaya (.csv, .xml) yeni bir veriolarak eklenir. Cevaplanan kısım diğer kısmı içerisinde yer alıyorsa önce sözcüklere ayırma ("tokenizing”) işlemi uygulanır. Daha sonra metinler küçük harflere dönüştürülür, sayı filtresi ile rakamlar temizlenir. Kelimeler köklerine ayrılır ("stemming”). Cümlelerdeki durdurma kelimeleri ("stop words") ve terim ağırlıklandırma ile bilgi sağlamayan gereksiz kelimeler temizlenir. Eğer bir anket çalışması yerine yalnızca alınan cevaplara göre öğrenme işlemi gerçekleştirilecek olursa yine aynı ön işleme işlemlerinin gerçekleştirilmesi büyük önem arz ettiği unutulmaması gerekmektedir. Konuyla ilgili hangi dilde kontrol yapılacaksa bir sözlük ("vocabulary") içerisinde kelimenin o sözlükte yer alıp almadığı kontrol edilir ve karar verilir.

Metin önişleme aşamasında, metin koleksiyonunun işlemlere hazır hale gelmesi amaçlanır. Bu doğrultuda; işaretleme, sözlük oluşturma, sonuca etki etmeyecek kelimeleri (stopwords) ayıklama, kelime köklerini bulma gibi işlemler yapılır. İş yükünü azaltmak için özellik seçimi yapılarak doğru sonuca ulaştıracak veriler seçilir (Oğuzlar, 2011).

\subsection{Stem}

Stem İngilizce'de kelimenin kökü anlamındadır. Fakat tam olarak Türkçe'deki kelime kökü anlamını karşılamaz. Bir metinde bulunan "yer", "yemek", "yeter" sözcükleri için stemming yapıldığında, üç kelimenin de kökü "ye-" olarak kabul edilir.

\subsection{Root}

Türkçe'deki anlam taşıyan kelime köküne karşılık gelir. 


\subsection{Stemming (Kök Bulma)}

Stemming kelimenin "stem"ini yani kökünü bulma işlemidir. Stemming NLP uygulanan dilin yapısına göre değişiklik gösterir.

Şekil 10. Stemming kök bulunması (Sirsat, 2013).

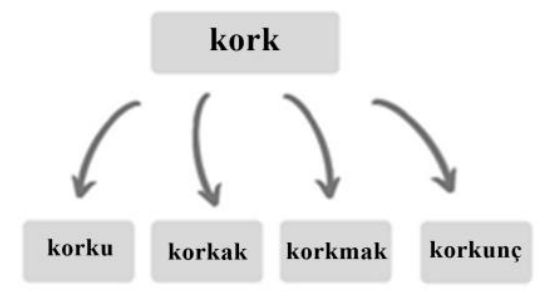

\subsection{Lemmatization}

Lemmatization kelimeleri morfolojik olarak inceler. Örnek olarak "Geliyorlar" kelimesi, gelmek fiilinin üçüncü çoğul şahıs geniş zamanda fiil çekiminden oluşur. Kelimenin fiil çekimi yapılmamış salt haline lemma denmektedir. "gelmek" bir lemmadır denir. Lemmatization algoritmaları çalışma esnasında bir sözlüğe gereksinim duyarlar.

\subsection{Tokenizing}

Sözcüklere ayırma yapılırken bir cümle, anlamlı daha küçük parçalara ayrılır. Sözcüklere örnek olarak semboller, kelimeler, deyimler gösterilebilir. Kullanılan ayrışturma aracına ("tokenizer") göre ayrıştırma yöntemleri değişmektedir.

Şekil 11. Ön İsleme Şekli (Dashtipour, 2016).

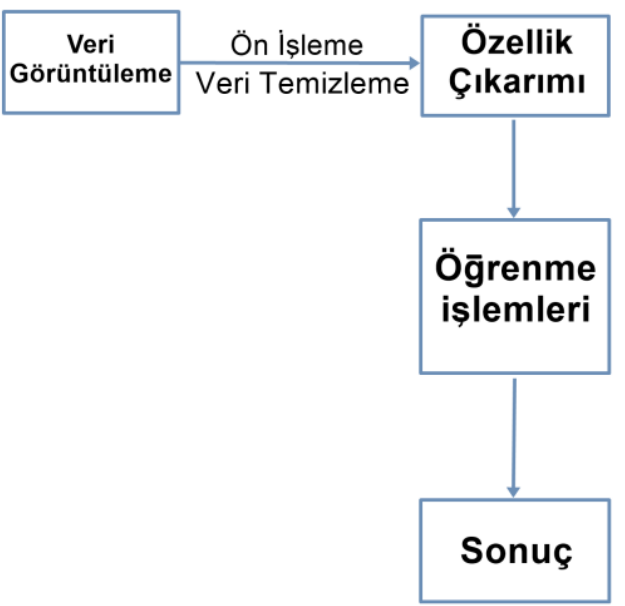

\subsubsection{Anamnez ile Alınan Sonuçların Kategorik Hale Getirilip Eğitilmesi}

Anketten alınan her bir soru değerlendirilir eğer çoklu seçim varsa her bir soruya karşıllı gelecek şekilde kategorik hale getirilir. Ön işleme aşamaları uygulanarak kategorik hale getirilen anamnez sonuçları, hastalık ismine göre sınıflandırılıp eğitim için kullanılır. Kategorik hale getirilirken alınan boy ve kilo bilgisinden vücut kitle indeksi hesaplanır. Her bir cevaba göre vücut kitle indeksi sonuçları değerlendirilmeye dahil edilir.

Sistemlerin gözden geçirilmesi altında yer alan tüm veriler çoklu bir kategori haline dönüştürülerek öğrenme metotlarına verilir. Hasta ya da hastalığı geçirmiş olan hastalardan alınan verilerden örnek bir çalışma aşağıda gösterilmiştir.
Ateş, öksürük, nefes darlı̆̆ı, boğaz ağrısı, baş ağrısı, kas ağrıları, tat ve koku alma kaybı veya ishal belirti ve bulgularından en az biri bulunması durumunda Covid-19 olabileceği düşünülmektedir (SağlıkBakanlığı, 2020).

Anamnez sırasında hastalara rahatsızlığ sorulduğunda, genelde bir tanı söyleyerek yakınmalarını anlatırlar, fakat hekimin anamnez alırkenki amacı hastanın semptomlarını öğrenmektir. Hekim, semptomların zaman içindeki gelişimini, nelerle tetiklenip nelerle rahatladığını değerlendirir. Böylece hastanın yakınmalarını tek tek belirleyerek ana semptomları ve eşlik eden semptomları sınıflandırır (ÖZTÜRK). Aşağıda belirtilen kategorik sonuç tabloları hastalardan solunum öyküsü sorusu altındaki cevaplardan alınmıştır. Solunum öyküsü semptomları örnek tablo olarak Tablo 9 ve Tablo 10'da verilmiştir. 
Tablo 9. Anketten Alınan Öykü ile Verilerin Kategorik Hale Getirilmesi Örneği

\begin{tabular}{|l|c|c|c|c|c|}
\hline & Kırgınlık & Ateş & Eklem Ă̆rısı & Öksürük & Nefes Darlı̆̆ \\
\hline Covid - 19 & + & + & + & + & + \\
\hline Mev. Grip & + & + & + & + & + \\
\hline Astım & + & & + & + & + \\
\hline Koah & & & & + & + \\
\hline Zatürre & & & & + \\
\hline Akut Bronşit & + & + & & & + \\
\hline Hepatit A-B-C & & & & & + \\
\hline
\end{tabular}

Tablo 10. Anketten Alınan Öykü ile Verilerin Kategorik Hale Getirilmesi Örneği

\begin{tabular}{|c|c|c|c|c|c|}
\hline & Boğaz Ağrısı & Burun Akıntısı & Baş Ağrısı & İshal & Kusma \\
\hline Covid - 19 & + & + & + & + & \\
\hline Mev. Grip & + & + & + & & \\
\hline Astım & & & + & & \\
\hline \multicolumn{6}{|l|}{ Koah } \\
\hline Zatürre & + & & & + & \\
\hline Akut Bronşit & & + & + & & \\
\hline $\begin{array}{l}\text { Hepatit A-B- } \\
\text { C }\end{array}$ & & & & & \\
\hline
\end{tabular}

Koah, astım, akut bronşit, zatürre, mevsimsel grip, Hepatit AB-C ve Covid-19 hastalıklarının kategorik hale getirilip veri seti oluşturulmuştur. Oluşturulan veri setinin \%25 oranında test veri seti oluşturularak doğruluk oranı belirlenmeye çalışılmıştır.

\section{2. Öykü'den (ANAMNEZ) Alınan Veriler ile Eğitim ve Öğrenme İşlemleri}

\subsection{1. Öğrenme Süreci}

Alınan verilerden Karar Ağaçları (Decision Trees), Topluluk (Ensemble) Öğrenme Yöntemleri olan Torbalama (Bagging) ve Artırma (Boosting) kullanılarak öğrenme yöntemleri uygulanmıştır.

Karar ağaçları ağaca benzer bir yapıda olduğu için isimlendirilmesi karar ağacı olarak adlandırılır. Bir karar ağacı basitçe bir soru sorar ve cevaba göre (Evet / Hayır) ağacı alt ağaçlara ayırır. Karar ağaçlarının, diğer sınıflama tekniklerine göre en önemli üstün tarafı, bilgiden çıkarılan kuralın anlaşılır bir şekilde yazılabilmesidir (TORAMAN, 2007).

Random Forest, farklı ağaç türlerine sahip bir toplu karar ağacı sınıflandırıcısıdır. Bölünmeyi belirlemek için her düğümde rastgele bir özellik dizisi kullanılarak ayrı bir karar ağacı üretilir. Her ağaç, alınan rastgele bir vektörün değerlerine dayanır. Ağaçları yükseltmek için CART yaklaşımı kullanılır. Mümkün olan maksimum boyuta yükseltilebilir ve budanmazlar. Random Forest, girdi özelliklerinden rastgele doğrusal kombinasyonları kullanır. Özelliklerin bir alt kümesini rastgele seçmez, ancak özelliklerin doğrusal bir kombinasyonu olan yeni öznitelikler oluşturur (Yaman, 2019).

Artırma (Boosting) birbirini tamamlayan modelleri bulmaya çalışarak bu fikirden yararlanmak için birden fazla modeli birleştirmek için kullanılır. Bu, sayısal tahmini tek bir modele göre sınıflandırmak veya ortalamak için oylamadan yararlanması açısından torbalamaya benzer. Diğer bir benzerlik ise, karar ağaçları gibi aynı türden modelleri bir araya getirmesidir. Boosting, yeni modelleri güçlendirir, böylece öncekiler tarafından yanlış şekilde kontrol edilen durumlar için uzman olurlar (Yaman, 2019).

\section{Araştırma Sonuçları ve Tartışma}

\section{1. Öykü'den (ANAMNEZ) Alınan Veriler ile Kullanılan Algoritmaların Sonuçları}

\subsubsection{Decision Tree (Karar Ăgaçları)}

Karar ağaçları, diğer algoritmalara oranla veri temizlemeye daha az ihtiyaç duymaktadır. Şekil 12'da görüldüğü üzere karar ağacı ile yapılmış sınıflandırma raporu yer almaktadır. 
Şekil 12. Karar Ağacı Sınıflandırma Raporu

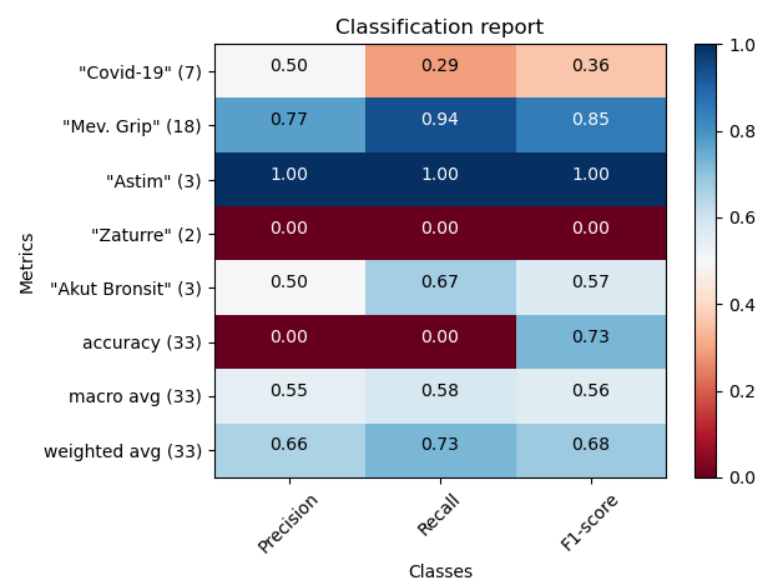

Toplamda 33 test verisi ile sınıflandırma işlemi gerçekleştirilmiştir. Şekil 13'de görüldüğü üzere karar ağac1

algoritmasından çıkan sonuç olan Karar Ağacı Hata Matrisi yer almaktadir.

\section{Şekil 13. Karar A ğacı Hata Matrisi}

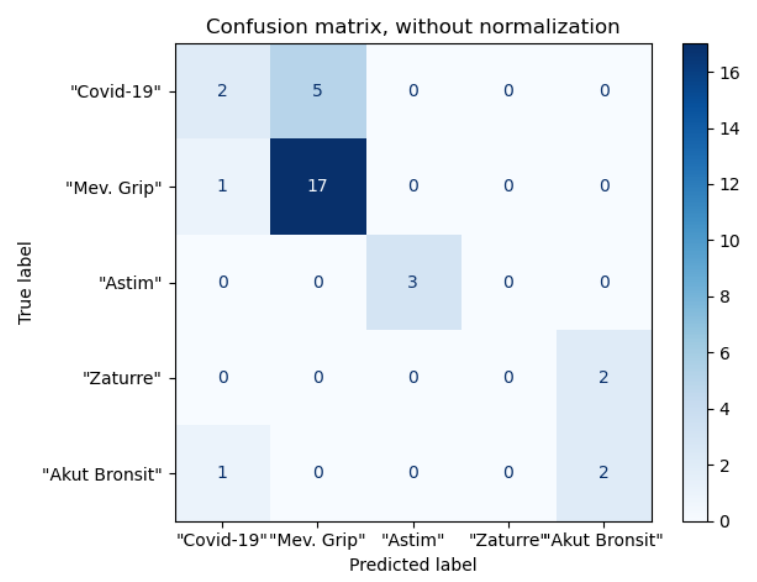

Karar ağacı algoritması sonucunda normalize edilmiş hata matrisi elde edilmişstir.

Elde edilen sonuçlar Karar Ağacı Normalleştirilmiş Hata Matrisi Şekil 14'de verilmiştir.

Şekil 14. Karar Ăgacı Normalleştirilmiş Hata Matrisi

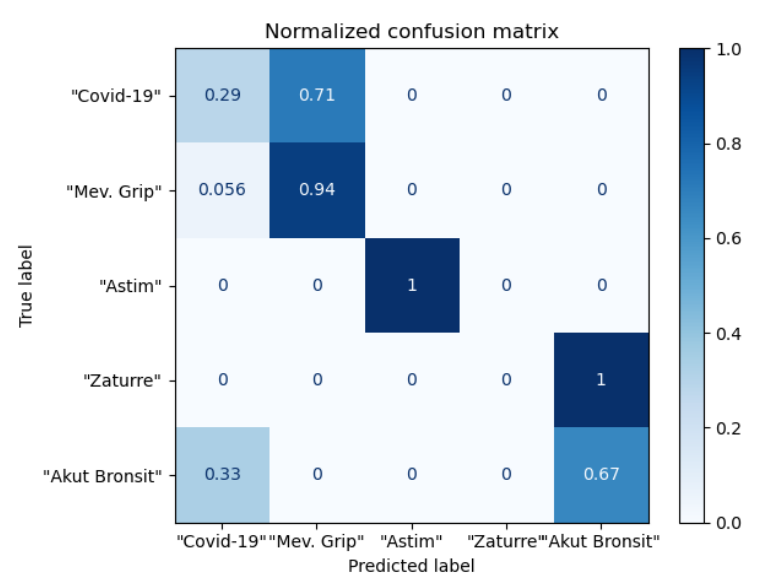

\subsubsection{Torbalama (Bagging)}


Anamnez ile alınan verilerin kategorik hale getirilmesinden sonra Random Forest algoritması kullanılarak verilerin öğrenme işlemi gerçekleştirilmiştir. Gerçekleştirilen öğrenme işlemi sırasında ölçüt olarak entropi ve gini ölçütleri kullanılarak testler yapılmıştır. Random Forest algoritması ve entropi ölçütü ile öğrenme işlemi gerçekleştirilmiştir. Yapılan öğrenme işleminde çıkan sonuçların sınıflandırma raporu Şekil 15'de yer almaktadır.

Şekil 15. Random Forest ve Entropi Ölçütü ile Sinıflandırma Raporu

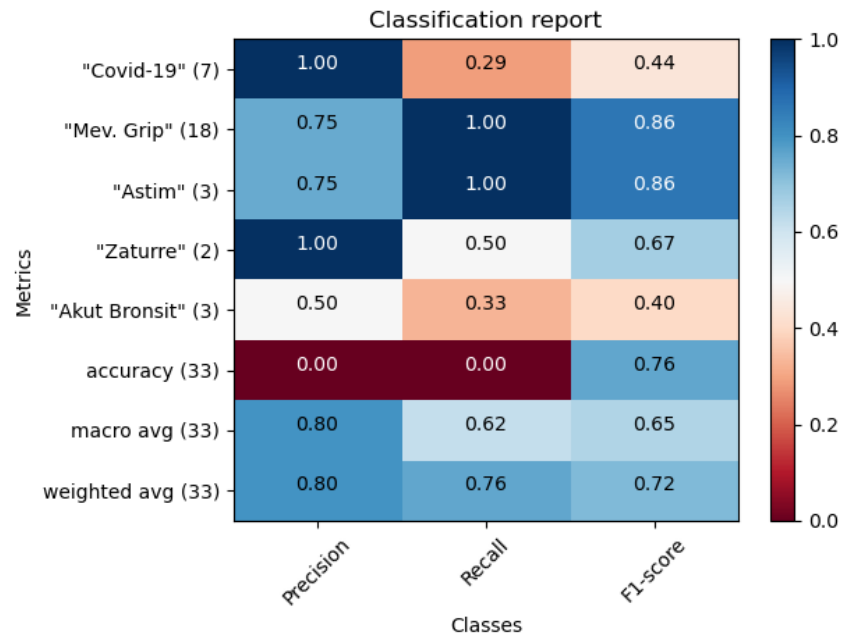

Random Forest algoritması kullanılıp entropi ölçütü ile yapılan öğrenme işlemi sonuçları, normalleştirilmiş hata matrisi ve hata matrisi şeklinde Şekil 16'da ve Şekil 17'de yer almaktadır.

Şekil 16. Random Forest ve Entropi Ölçütü ile Hata Matrisi

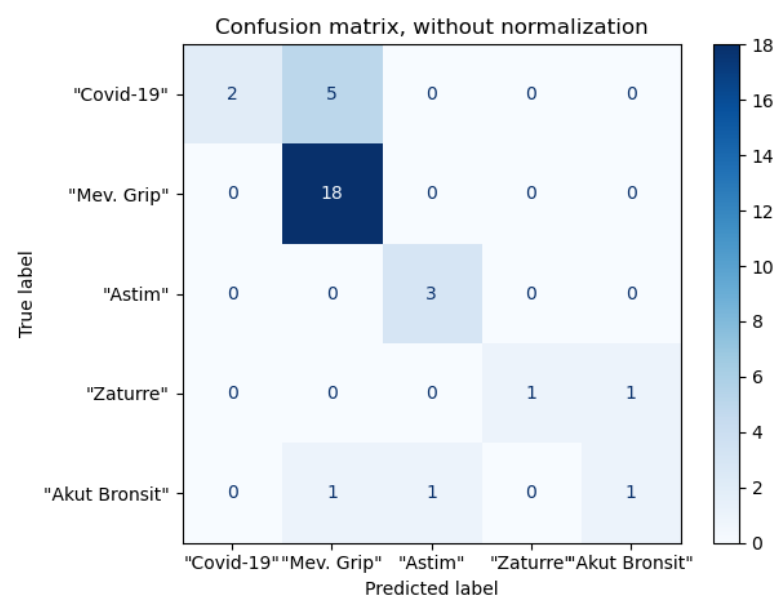

Şekil 17. Random Forest ve Entropi Ölçütü ile Normalleştirilmiş Hata Matrisi 


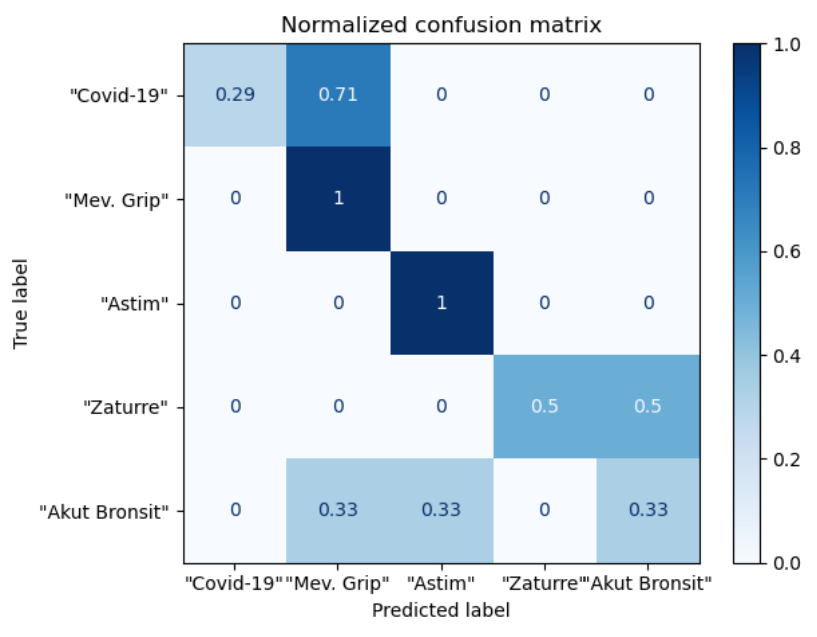

Random Forest algoritması kullanılıp Gini ölçütü ile yapılan öğrenme işlemleri gerçekleştirilmiştir.

Gini ölçütü ile yapılan öğrenme işleminde çıkan sonuçlara Şekil 18'de yer verilmiştir.

Şekil 18. Random Forest ve Gini Ölçütü ile Sınıflandırma Raporu

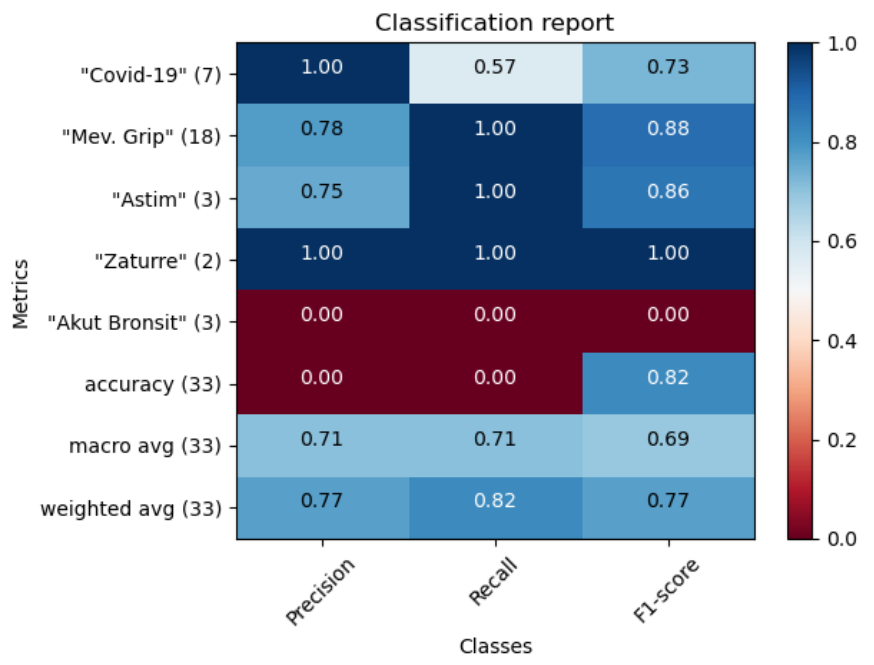

Random Forest algoritması ve Gini ölçütü kullanılarak yapılan öğrenme işlemi sonuçları, normalleştirilmiş hata matrisi ve hata matrisi şeklinde Şekil 19 ve Şekil 20'te yer almaktadır.

Şekil 19. Random Forest ve Gini Ölçütü ile Hata Matrisi

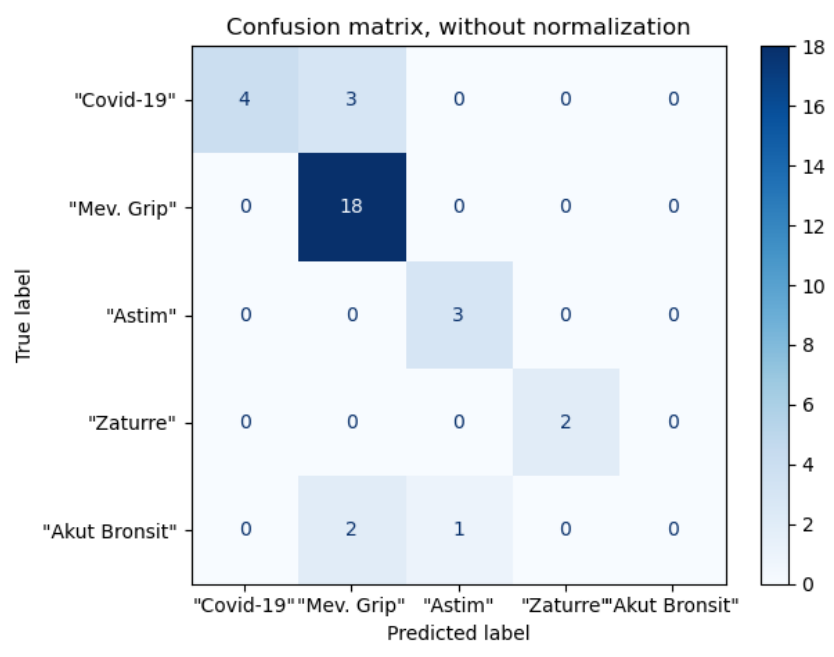


European Journal of Science and Technology

Şekil 20. Random Forest ve Gini Ölçütü ile Normalleştirilmiş Hata Matrisi

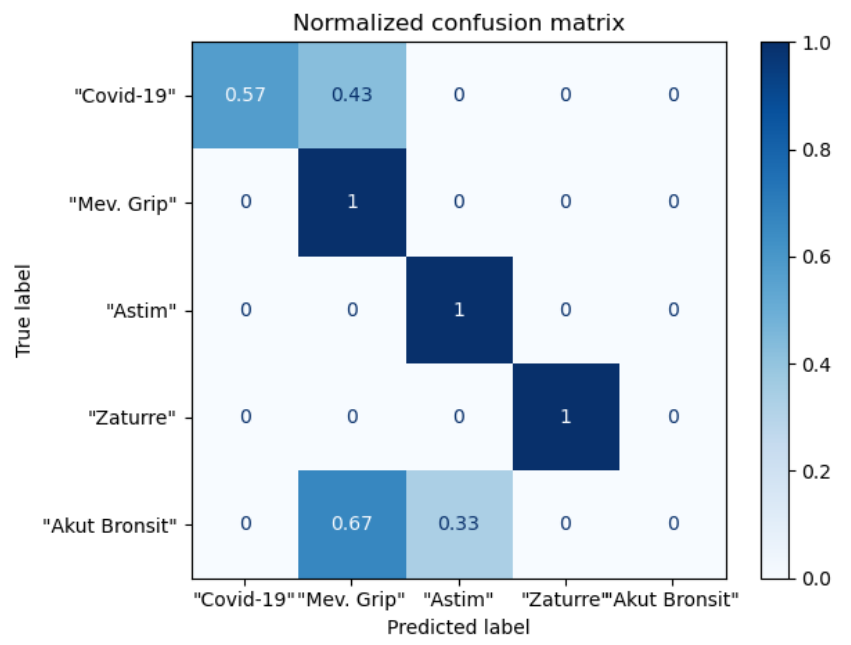

\subsubsection{Artırma (Boosting)}

Anamnez ile alınan verilerden Adaboost algoritması kullanılarak verilerin öğrenme işlemi gerçekleştirilmiştir.
Gerçekleştirilen öğrenme işlemi sırasında ölçüt olarak öğrenme sabiti "1.0" kullanılarak testler yapılmıştır. Öğrenme işleminden sonra çıkan sonuçlar Şekil 21'de yer almaktadır.

Şekil 21. Adaboost Algoritması ve Öğrenme Sabiti “1.0” ile Sinıflandırma Raporu

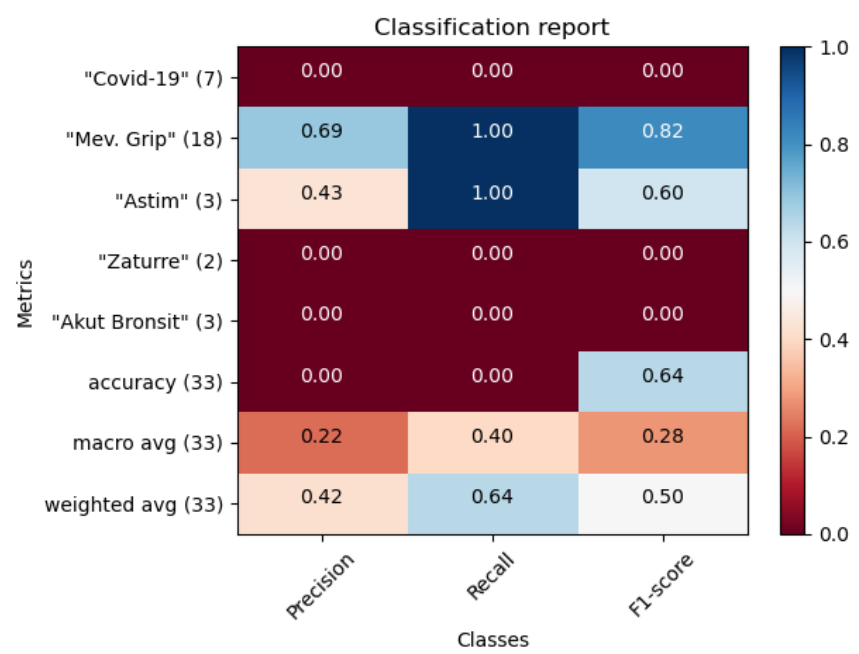

Adaboost algoritması kullanılarak yapılan öğrenme işlemi sonuçları, normalleştirilmiş hata matrisi ve hata matrisi şeklinde Şekil 22 ve Şekil 23'de yer almaktadır. 


\section{Avrupa Bilim ve Teknoloji Dergisi}

Şekil 22. Adaboost Algoritmast ve Öğrenme Sabiti “1.0” ile Hata Matrisi

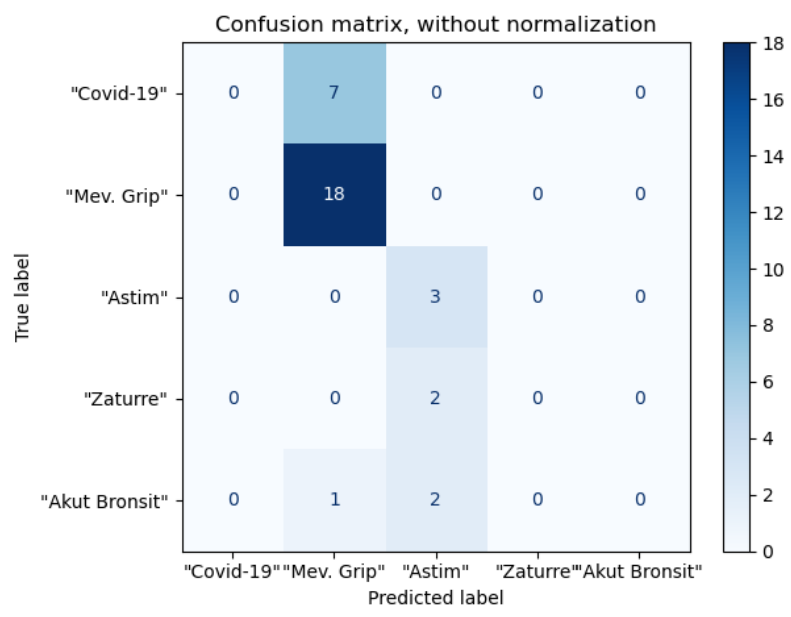

23. Adaboost Algoritması ve Öğrenme Sabiti "1.0" ile Normalleştirilmiş Hata Matrisi

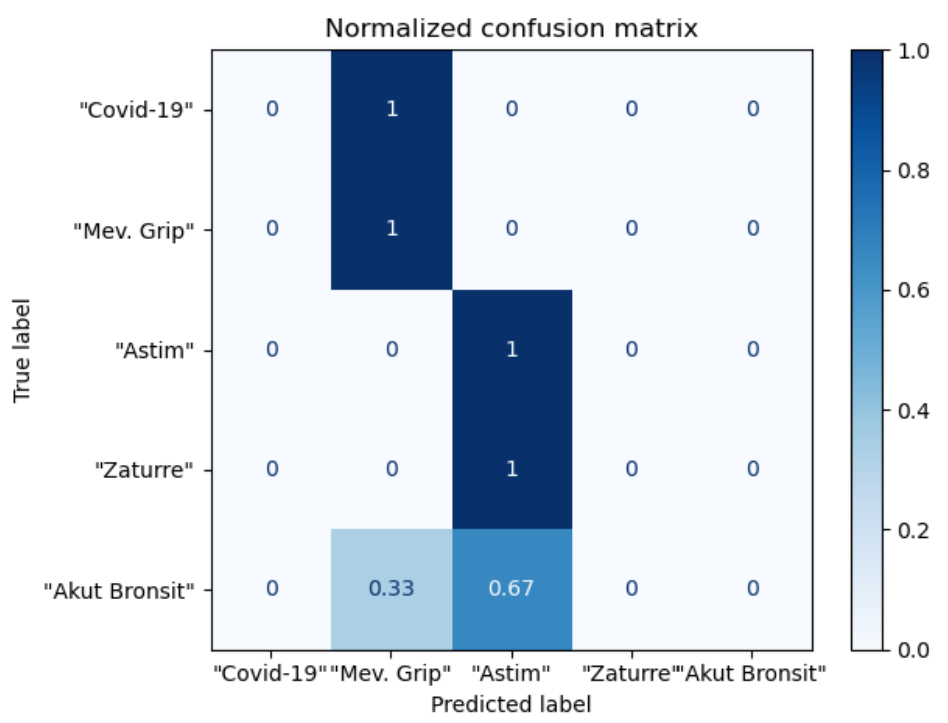

Adaboost algoritması ile gerçekleştirilen öğrenme işlemi

yapılmıştır. Öğrenme işleminden sonra çıkan sonuçlara Şekil sırasında ölçüt olarak öğrenme sabiti " 0.5 " kullanılarak testler 24'de yer verilmiştir.

\section{Adaboost Algoritması ve Öğrenme Sabiti “0.5” ile Sinıflandırma Raporu}

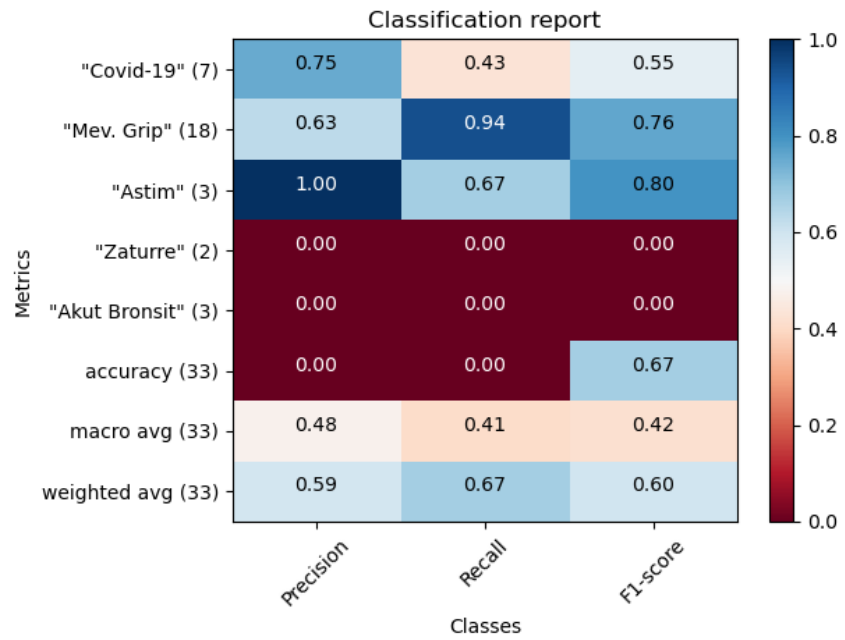


Adaboost algoritması ile gerçekleştirilen öğrenme işlemi sırasında ölçüt olarak öğrenme sabiti " 0.5 ” kullanılarak ile yapılan öğrenme işlemi sonuçları, Normalleștirilmiş hata matrisi ve hata matrisi şeklinde Şekil 25 ve Şekil 26 'da yer almaktadır.

\section{Adaboost Algoritmast ve Öğrenme Sabiti "0.5” ile Sinuflandirma Raporu}

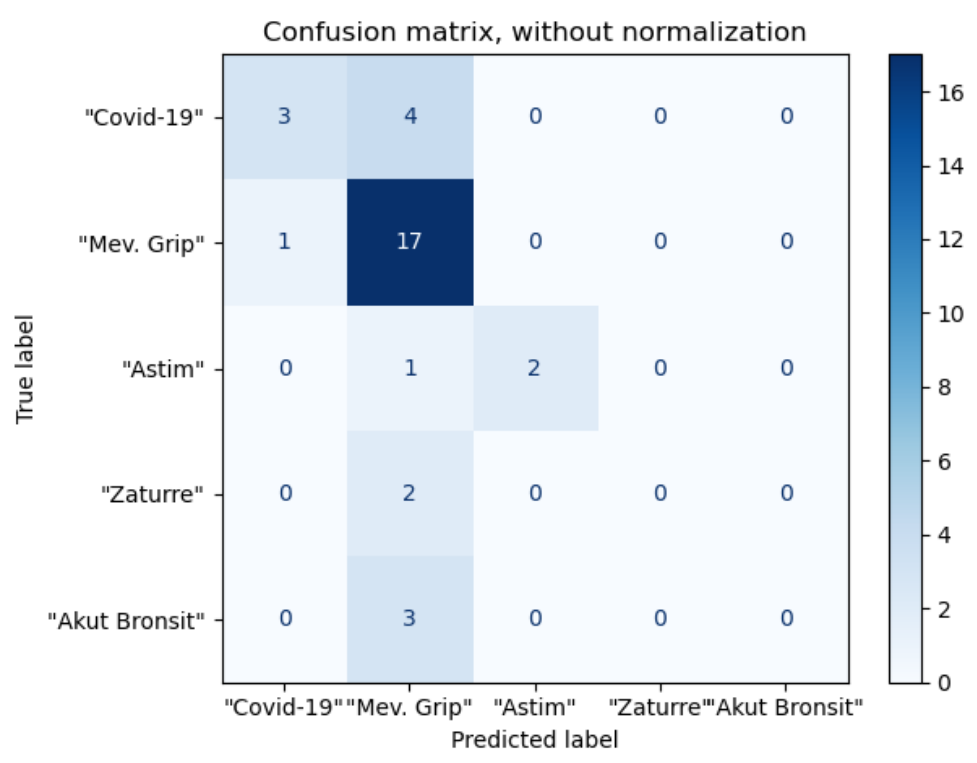

26. Adaboost Algoritması ve Öğrenme Sabiti “0.5” ile Normalleştirilmiş Hata Matrisi

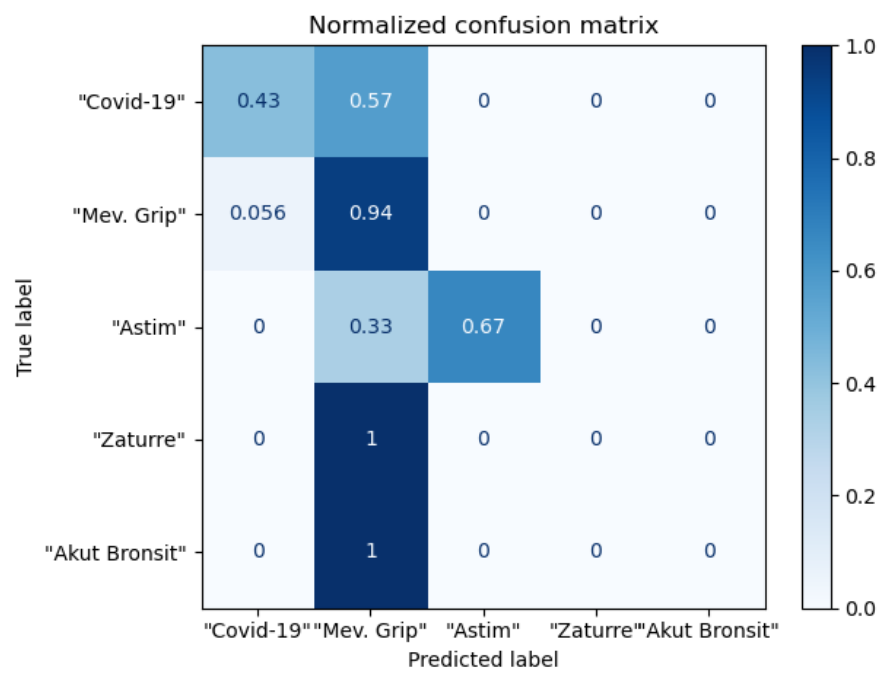

\section{Sonuç}

Bu makalede Karar Ağaçları, Torbalama ve Artırma gibi teknikler kullanılmıştır. Bu teknolojiler gelecekte belki de herhangi bir doktorun varlığına ya da yardımına ihtiyaç duymadan birçok hastalığın tedavi ve tanı yöntemlerinde kullanılacaktır.

Yapılan çalışmaya göre hasta öyküsü almanın (Anamnez) büyük bir önemi olduğu görülmüştür. Doğru alınan öykü ile birçok hastalı̆ıın erken aşamada tanısı gerçekleştirilerek hastalığın erken safhasında tedaviye başlanması sağlanabilir. Hayati önem arz eden birçok hastalık çeşidi (az veri setinin bulunduğu durumlarda bile) bu makaledeki yöntemler kullanılarak doğru şekilde tanınabilir ve yüksek doğruluk oranına sahip, hekime yardımc1 bir tanı koyma sistemi olarak kullanılabilir. Aşağıdaki tabloda bu makalede kullanılan yöntemlerin doğruluk oranları gösterilmektedir. 


\begin{tabular}{|c|c|c|}
\hline \multirow{2}{*}{ Karar Ağaçları (Decision Tree) } & \multicolumn{2}{|c|}{ Doğruluk Oranları } \\
\hline \multirow{2}{*}{ Random Forest Algoritması } & Entropi & Gini \\
\cline { 2 - 3 } & 0.76 & 0.82 \\
\hline \multirow{2}{*}{ Adaboost Algoritması } & Öğrenme Sabiti $=1.0$ & Öğrenme Sabiti $=0.5$ \\
\cline { 2 - 3 } & 0.64 & 0.67 \\
\hline
\end{tabular}

Aynı zamanda günümüzdeki pandemi dönemi gibi yeterli sağlık personeline ulaşılmasının zor olduğu durumlarda bu sistem ile gelişmiş bir teknolojik alt yapı oluşturularak belirli hastalıkların tesbiti yapılabilir. Gelecekte, sağlık sektöründe yapılacak teknolojik alt yapı çalışmaları ile bir bölümü yapay zeka teknolojisinden yararlanarak çok daha hızlı ve doğru hastalık tanısı koyarak hastanın en doğru şekilde iyileşme süreci sağlanacaktır.

\section{Kaynakça}

Acıbadem. (2021, şubat). acibadem. acibadem: https://www.acibadem.com.tr/ilgi-alani/vucut-kitle-indeksihesaplama/\#genel-tanitim adresinden alındı

Alçelik, A. (2016). Anamnez Hikaye Alma.

Atharva Bankar, Kewal Padamwar, Aditi Jahagirdar (Ocak 2021), Symptom Analysis using a Machine Learning approach for Early Stage Lung Cancer, 2020 3rd International Conference on Intelligent Sustainable Systems (ICISS)

Berna Arı , Ali Arı, Abdulkadir Şengür (Mart 2020), Suicide Prediction from Hemogram with Machine Learning, Avrupa Bilim ve Teknoloji Dergisi

Choi, S. (2020). An Ensemble Learner-Based Bagging Model Using Past Output Data for Photovoltaic Forecasting. energies.

Dashtipour, K. (2016). Multilingual Sentiment Analysis: State of the Art and Independent Comparison of Techniques.

Dhiyaussalam, Adi Wibowo, Fajar Agung Nugroho, Eko Adi Sarwoko, I Made Agus Setiawan (December 2020), Classification of Headache Disorder Using Random Forest Algorithm, 2020 4th International Conference on Informatics and Computational Sciences (ICICoS)

Fakültesi, A. Ü. (2016). Tibbi Hikaye ve Fizik Muayene Pratik Soru Örnekleri ve Yanitları.

Guan-Hua Huang, Chih-Hsuan Lin, Yu-Ren Cai, Tai-Been Chen, ShihYen Hsu, Nan-Han Lu (Ağustos 2020), Multiclass machine learning classification of functional brain images for Parkinson's disease stage prediction, Ministry of Science and Technology, Taiwan

George Monks, Ryan Rivera-Oyola, Mark Lebwohl (2021), The Psoriasis Decision Tree, J Clin Aesthet Dermatol.

İbrahim Türkoğlu ve Suat Toraman (Ağustos 2007), Karar Ağaçları ve Fraktal Analiz Kullanarak Histopatolojik İmgelerin Sinıflandırılması, Gazi Üniv. Müh. Mim. Fak. Der.

Kellner, T. (2017, 12 04). ge: https://www.ge.com/news/reports/aihealthcare-expert-doctors-machines-make-brilliant-match adresinden alındı

Kellner, T. (2017, Aralık). AI Healthcare Expert: Doctors And Machines Make A Brilliant Match. https://www.ge.com/news/reports/aihealthcare-expert-doctors-machines-make-brilliant-match. adresinden alınd

Kilınç, D. (2016). The Effect of Ensemble Learning Models on Turkish Text Classification. CBÜ Fen Bil. Dergi., Cilt 12, Sayı 2, 215-220 s.
Lupaşcu, C. A., Tegolo, D., \& Trucco, E. (2013). Accurate estimation of retinal vessel width using bagged decision trees and an extended multiresolution Hermite model. Medical image analysis

Nalçac1, R. (2015). Anamnez Formu.

Oğuzlar, A. (2011). Temel metin madenciliği.

Oya Kayacan, Ö. K. (2018). Göğüs Hastalıklarında Anamnez Ve Fizik Muayene.

ÖZTÜRK, N. A. (tarih yok). SOLUNUM SÍSTEMI HASTALIKLARINDA ANAMNEZ VE BAŞLICA SEMPTOMLARIN DEĞERLENDİRILMESİ.

Saad, M. $(2019,12)$. mksaad.wordpress. mksaad. adresinden alındı

$\begin{array}{llll}\text { SağlıkBakanlığ } 1, & \text { T. (2020). } & \text { Covid-19 GENEL }\end{array}$ BILLGILER,EPIDEMIYOLOJI VE TANI.

Sevinç, S. (2006). Kardiyovasküler Sistemin Değerlendirilmesi. Hemşirelikte Eğitim ve Araştırma Dergisi.

Sirsat, S. R. (2013). Strength and Accuracy Analysis of Affix Removal. International Journal of Computer Science and Information Technologies.

STEFANOWSKI, J. (2010). Discovering Decision Trees. Institute of Computing Science Poznań University of Technology.

Taçnur İlaslaner, Ayşegül Güven (Kasım 2019), Investigation of the Effects Biochemistry on Iron Deficiency Anemia, Medical Technologies Congress (TIPTEKNO)

Tarhan, Ö. R. (2015). turkcerrahi. turkcerrahi.com. adresinden alındı

TORAMAN, İ. T. (2007). KARAR AĞAÇLARI VE FRAKTAL ANALIZ KULLANARAK HISTOPATOLOJIK IMGGLERIN SINIFLANDIRILMASI . Gazi Üniv. Müh. Mim. Fak. Der.

Uygun, A. (2009). Tıbbın Olmazsa Olmazı Fizik Muayeneyi İhmal mi Ediyoruz? Ankara: Gülhane Askeri Tıp Akademisi, Gastroenteroloji Kliniği.

V. Bhargavi Rao, David Schellenberg, Azra C. Ghani1(Temmuz 2013), The Potential Impact of Improving Appropriate Treatment for Fever on Malaria and Non-Malarial Febrile Illness Management in Under5s: A Decision-Tree Modelling Approach

Vidit Laijawala; Aadesh Aachaliya; Hardik Jatta; Vijaya Pinjarkar (Temmuz 2020), Classification Algorithms based Mental Health Prediction using Data Mining, 5th International Conference on Communication and Electronics Systems (ICCES)

Yaman, E. (2019). Comparison of Bagging and Boosting Ensemble Machine Learning Methods for Automated EMG Signal Classification. Hindawi BioMed Research International . 